\title{
Review on Nepal's Increasing Agricultural Import
}

\author{
Suresh Simkhada* \\ Department of Agriculture, Nepal \\ *Corresponding Author: Suresh Simkhada, Department of Agriculture, Nepal.
}

Received: July 15, 2019; Published: September 16, 2019

DOI: $10.31080 /$ ASAG.2019.03.0650

\begin{abstract}
Despite being agricultural country Nepal is importing huge amount of agricultural commodities from other countries to fulfill the need of its people. So some research articles and news reports were table reviewed to find the reasons behind the skyrocketing import of agricultural goods. Low productivity coupled with increasing population, changing lifestyle of people, increasing number of food processing and feed companies, high cost of production, diversion of agricultural loan to non-productive sector and lack of storage are major reasons that are supporting to increasing agricultural import. Nepal should increase the production and productivity of agricultural commodities and make investment in agricultural sector rather than in non-productive sector to reduce the increasing agricultural import and jack up the export. In addition people also change their food habit and use the products of own products rather than giving emphasis to foreign goods.

Keywords: Agriculture Commodities; Import; Production; Productivity; Consumption
\end{abstract}

\section{Introduction}

Nepal is country with economy based on agriculture. The recent data from government revealed that agriculture sector contribute about $27.1 \%$ of GDP and employ 65.6 percent of labour force in Nepal. Despite the involvement of the huge chunk of population in agriculture, Nepal is importing agriculture goods from other countries for daily consumption. Nepal used to export agriculture commodity like paddy, lentil and legumes to other countries in the past, but the scenario is reversed these days. Nepal's global trade is imbalanced and unhealthy not only for agriculture goods but also in overall. There is large chasm between imports and exports which is growing day by day leading to soaring trade deficit. Nepal isn't able to increase its export due to conglomeration of export items; there are only few commodities in export basket of Nepal. Only ten export commodities occupies more than two third share (66.1\%) of total export. From regional perspective too, Nepal export its goods to limited countries and regions. Nepal export almost three quarters (72.3\%) of total export to Asian countries and more than three fifth $(61.8 \%)$ of trade is only with India.

Nepal export different agricultural products like cardamom, tea, coffee, ginger, lentil, vegetables and import large amount of food grain, edible oils, spices, animal feeds and different animal products from other countries. The export amount isn't increasing but the import is sky rocketing. Nepal's agricultural goods import crossed NRs. 200 billion for the first time in the fiscal year $2016 / 17$, propelling an already bloated trade deficit to its highest level on record. Major imports of Nepal are machineries and petroleum products but the portion of agricultural products in the total import has also step up to 17 percent. In list of agricultural import cereal placed itself on top followed by edible oil, vegetables, animal feeds and fodder, fruits and nuts.

The major reasons of surging agricultural import are low productivity of agricultural goods and changing life style of middle class people. But beside these, there are several reasons behind increasing agricultural import of Nepal.

\section{Increasing population and decreasing productivity}

Population of Nepal is increasing rapidly but the production of food crops is not increasing in the same ratio. The production and productivity of the crops like paddy, lentil, spices crops, oil crops and fruits has decreased this year instead of increasing. The low productivity of agriculture is due to less commercialization and mechanization. Large population involved in agriculture are subsistence type. Only $25.1 \%$ of farmers are doing commercial farming and remaining $75.9 \%$ doing subsistence farming. The main obstacle for farmers to do commercial farming is land fragmentation. The average land holding of Nepalese is 0.6 ha and $51.1 \%$ of household have land holding less than 0.5 ha according to the report of 2016 .

Moreover, there is very low production of oil crops, spices crops and nut fruits in Nepal due to several agronomic and climatic constraints. So, to fulfill the demand of increasing population also Nepal is importing agricultural goods from other countries. 
Increase in food processing and feed companies

Growing number of food processing industries and feed companies inside the country has caused the huge import of cereals from outside. Expansion in the livestock industries like poultry, aqua culturing, cattle rearing has increased the demand of the feeds in country and many food and feed industries are being established. Mainly grains used in food and feed industries are imported from foreign countries due to low quality of national product like maize, wheat, barley, oat etc. So, this is another main reason for the surging cereals import.

\section{Changing life style and food habit of the people}

Another main reason for growing import is changing life style and food habit of the Nepalese people. In one hand, Nepalese people are becoming health conscious and increasing the amount of vegetables and fruits in their diet. People think that foreign goods with higher price are of higher quality. They think foreign commodities are higher in quality and prefer to consume the imported commodities.

In other hand, Nepalese people prefer to have spicy and tasty foods and believe that more oils make food tastier. But, there is low production of spices crops and oil crops inside the country. Portion of middle class people in Nepal is increasing day by day who don't want to work in the field but prefer to consume by purchasing rather than producing themselves.

\section{Diversion of agricultural loan to non-productive sector}

Huge amount of agricultural loan given by financial institution and government grants are invested in non-productive sectors like housing, real estate and other business. People take soft loan and agricultural loan but invest in other sector. The agricultural loan has increased by $167 \%$ in last five years and financial institutions have invested 1804.2 billion in agriculture sector, production and productivity is decreasing.

\section{Out migration and high cost of production}

Significant outmigration of youths have resulted in the scarcity of work force in villages. This has increased the cost of production and finally the price of produced goods. But the price of Indian agricultural goods like vegetables and fruits is relatively low due to low cost of production. India give relatively high subsidies and support to farmers than in Nepal. So, it would be cheaper to buy from India than producing inside the country. Most of the agriculture land in the village are left uncultivated due to outmigration or used for other purposes. The entered remittance is used for purchasing consumption goods rather than investing in agriculture.

\section{Lack of storage and processing}

Lack of physical infrastructure like storage house, cold storage and processing plant are also uplifting the agricultural import in Nepal. The produced products are not getting market due to lack of infrastructure like road electricity, storage and market. So people in one part are importing food for consumption while they are being wasted in another part [1-9].

\section{Conclusion}

Agriculture import of Nepal is booming and remittance is only the factor that has helped keep the country's economy afloat. Of several reasons decreasing productivity coupled with increasing population, changing life style and food habit of people, increasing number of food processing and feed companies, diversion of agricultural investment and loan to non-productive sector, land fragmentation, high cost of production and lack of storage and processing are major factors that have jack up the agricultural import of Nepal. To improve the economy and make prosperous nation first import must be reduced and export should be boost up. Researches should be focused on increasing the production and productivity of Nepalese agriculture and some special schemes should be brought to lower the production cost and attract the youth to commercial agriculture. People should give priority to national product and storage houses and processing plant should be established to minimize the agricultural import.

\section{Bibliography}

1. Economics T. “Nepal Food Inflation” (2019).

2. Ghimire LS. Nepal's Widening Trade Deficit; Some Issues, Challenges and Recommendations. Economic Management Division. Kathmandu: National Planning Commission Secretariat (2016)..

3. Kaini BR. “Why import food?” My Republica (2016).

4. MoF. "Nepal foreign trade statistics fiscal year 2016/17”. Department of Customs (2017).

5. Nepal Export, and its import. The Himalayan Times (2018).

6. Paudel MN. "Prospects and limitations of agriculture industrialization in Nepal”. Agronomy Journal of Nepal 4 (2016): 37-63.

7. Prasain S. "Agro products import bill crosses NRs200 billion". The Kathmandu Post (2018).

8. TEPC. "A Glimpse of Nepal's Foreign Trade”. Pulchowk, Lalitpur: Trade and Export Promotion Centre (2017).

9. Workman D. "Nepal's Top 10 Exports". World Trade Exports (2018).

Volume 3 Issue 10 October 2019

(C) All rights are reserved by Suresh Simkhada. 